\title{
Microbial background flora in small-scale cheese production facilities does not inhibit growth and surface attachment of Listeria monocytogenes
}

\author{
B. C. T. Schirmer, ${ }^{* 1}$ E. Heir, ${ }^{*}$ T. Møretrø, ${ }^{*}$ I. Skaar, $†$ and S. Langsrud ${ }^{*}$ \\ *Nofima - Norwegian Institute of Food, Fisheries and Aquaculture Research, PO Box 210, N-1431 Ås, Norway \\ †Norwegian Veterinary Institute, PO Box 750 Sentrum, N-0106 Oslo, Norway
}

\begin{abstract}
The background microbiota of 5 Norwegian smallscale cheese production sites was examined and the effect of the isolated strains on the growth and survival of Listeria monocytogenes was investigated. Samples were taken from the air, food contact surfaces (storage surfaces, cheese molds, and brine) and noncontact surfaces (floor, drains, and doors) and all isolates were identified by sequencing and morphology (mold). A total of 1,314 isolates were identified and found to belong to 55 bacterial genera, 1 species of yeast, and 6 species of mold. Lactococcus spp. (all of which were Lactococcus lactis), Staphylococcus spp., Microbacterium spp., and Psychrobacter sp. were isolated from all 5 sites and Rhodococcus spp. and Chryseobacterium spp. from 4 sites. Thirty-two genera were only found in 1 out of 5 facilities each. Great variations were observed in the microbial background flora both between the 5 producers, and also within the various production sites. The greatest diversity of bacteria was found in drains and on rubber seals of doors. The flora on cheese storage shelves and in salt brines was less varied. A total of 62 bacterial isolates and 1 yeast isolate were tested for antilisterial activity in an overlay assay and a spoton-lawn assay, but none showed significant inhibitory effects. Listeria monocytogenes was also co-cultured on ceramic tiles with bacteria dominating in the cheese production plants: Lactococcus lactis, Pseudomonas putida, Staphylococcus equorum, Rhodococcus spp., or Psychrobacter spp. None of the tested isolates altered the survival of L. monocytogenes on ceramic tiles. The conclusion of the study was that no common background flora exists in cheese production environments. None of the tested isolates inhibited the growth of $L$. monocytogenes. Hence, this study does not support the hypothesis that the natural background flora in cheese production environments inhibits the growth or survival of $L$. monocytogenes.
\end{abstract}

Received November 20, 2012.

Accepted May 17, 2013.

${ }^{1}$ Corresponding author: Bjorn.Schirmer@nofima.no
Key words: flora, cheese, small scale, Listeria monocytogenes

\section{INTRODUCTION}

To produce safe food for consumers, food producers have a strong focus on hygiene during production. Cleaning and disinfection are the most common means of obtaining safe production environments, but even though daily cleaning and disinfection will significantly reduce the bacterial load in the production environment, surfaces are rarely sterile (Langsrud et al., 2012). At the same time, although most food products (including meat, fish, fruits, and vegetables) are produced or processed in clean environments, food types exist that are produced in the presence of a rich microbial background flora. In the production of cheese, disinfection is often avoided or performed rarely in the storage facilities to preserve a bacterial background flora, as it is considered to be important for the quality of the product (Retureau et al., 2010).

In recent years, cheese and other milk products have been the source for several outbreaks of listeriosis (Carrique-Mas et al., 2003; Gaulin et al., 2003; Makino et al., 2005; Bille et al., 2006; Swaminathan and GernerSmidt, 2007; Vít et al., 2007; Fretz et al., 2010; Johnsen et al., 2010; Gaulin et al., 2012). Listeria monocytogenes, the causative agent of listeriosis, is known to survive and grow well under conditions that inhibit a range of other bacteria, including low temperatures and high salt concentrations (Larson et al., 1999; Lado and Yousef, 2007). It does, however, not grow well at low $\mathrm{pH}$ (Lado and Yousef, 2007) and the presence of lactic acid bacteria, both naturally occurring and added during production, would hence inhibit further growth of Listeria in the cheese during the ripening period. However, as surface cultures (molds or bacteria) are commonly added during ripening of the cheese, a rise in $\mathrm{pH}$ may occur and conditions may allow for growth of Listeria to high numbers, especially close to the cheese surface (Bell and Kyriakides, 2005).

As Listeria is killed by pasteurization (Lado and Yousef, 2007), the main cause for the presence of vi- 
able Listeria in pasteurized milk and cheese from pasteurized milk is recontamination from the processing environment. It has been shown that $L$. monocytogenes is able to survive and persist in food production environments (Romanova et al., 2002; Di Bonaventura et al., 2008) and due to this, may pose a threat to food safety. Unpasteurized milk may contain Listeria even if no source for recontamination from the cheese production environment exists (Bemrah et al., 1998) but it has been shown that the bacterial background flora in raw milk may inhibit the growth of $L$. monocytogenes (Schvartzman et al., 2011). It is hence of interest to investigate whether the naturally occurring background flora in the cheese production environment may also have a protective effect against Listeria.

To establish whether the microbial background flora in the cheese production environment may have any protective effect against L. monocytogenes, it is necessary to know the composition of this flora. While many studies have focused on the bacterial flora in raw milk or cheese (Retureau et al., 2010; Fricker et al., 2011), few have studied the background flora in the whole cheese production environment, despite the fact that the flora on materials in direct contact with cheese has been shown to vary at different locations (Licitra et al., 2007; Mariani et al., 2007). Several studies have shown that various bacterial species can influence survival, growth, and adherence of $L$. monocytogenes to surfaces (Leriche et al., 1999; Leriche and Carpentier, 2000; Carpentier and Chassaing, 2004; Guð̋björnsdóttir et al., 2005), but no direct connection has been made between the common background flora in cheeseproducing environments and the growth and survival of $L$. monocytogenes in production environments. This study shows in detail the composition of the microbial background flora in 5 Norwegian small-scale cheese production sites and how the isolated strains influence the growth of $L$. monocytogenes in a model system and in co-culture biofilms.

\section{MATERIALS AND METHODS}

\section{Sampling and Microbial Culture Conditions}

Five small-scale cheese-producing farms (ranging from 1 to 7 employees and production volumes from 2 to $10 \mathrm{t}$ per year) in Norway were visited in the period between February and May 2010. All farms had their own milk production and used one set of production equipment to produce several types of cheese, including at least 1 type of soft cheese (Camembert or Brie type). Ripening rooms contained more than 1 type of cheese at all producers, but sampling was conducted in areas adjacent to soft cheeses. Four farms used pasteurized milk in their production, whereas 1 farm (producer 4) used unpasteurized milk. All farms produced cheeses that were salted in brines and inoculated with surface molds. At each farm, 8 sites were sampled (Supplemental Table S1, available online at http://dx.doi. org/10.3168/jds.2012-6395) using sampling swabs in Letheen broth (3M Norge AS, Skjetten, Norway) as well as at least 1 out of 2 Listeria-selective all-in-one swabs (InSite Listeria Test; Labolytic, Trondheim, or the Path-Chek Hygiene Listeria; Interfarm AS, Asker, Norway). In addition, plate count agar (PCA) plates (Oxoid Ltd., Basingstoke, UK) were placed without lids for $10 \mathrm{~min}$ in the production rooms and the ripening rooms for air samples. Brines $(1 \mathrm{~mL})$ were sampled directly by pipetting. For each selected location, 2 areas of $5 \times 5 \mathrm{~cm}$ within $10 \mathrm{~cm}$ distance were swabbed thoroughly and the swabs were kept in a cooling bag until they reached the laboratory within $24 \mathrm{~h}$ after sampling. Appropriate dilutions of the Letheen broth and the brine were plated on PCA and the plates were incubated aerobically at $20^{\circ} \mathrm{C}$ for $5 \mathrm{~d}$. The Listeriaselective swabs were kept following the manufacturer's instructions and examined for color changes after 1 and $2 \mathrm{~d}$ as indicated in the manuals.

\section{Determination of the Microbial Flora: Bacteria}

From each sample, 24 colonies were picked randomly from PCA plates and subjected to partial sequencing of the $16 \mathrm{~S}$ ribosomal DNA (rDNA) gene to identify the isolated strains. All colonies were recultured on PCA for $3 \mathrm{~d}$ at $20^{\circ} \mathrm{C}$ to rule out contaminations. From these plates, 1 to 15 colonies (15 for small colonies to ensure enough cell material) were picked and mixed with Tryptone soy broth (TSB; $45 \mu \mathrm{L}$; Oxoid Ltd.), guanidine thiocyanate (GTC; $4 \mathrm{~mol} / \mathrm{L}, 135 \mu \mathrm{L}$; Merck KGaA, Darmstadt, Germany) and Mag Prep Silica Particles $(10 \mu \mathrm{L}$; Merck KGaA) in wells of a 96-well Greiner U plate (Greiner Bio-One GmbH, Frickenhausen, Germany). The DNA was isolated on a Biomek 2000 Workstation (Beckman Coulter Inc., Fullerton, CA) using magnetic silica particles and sarkosyl (Skånseng et al., 2006). Polymerase chain reaction of the $16 \mathrm{~S}$ rDNA was conducted using DyNAzyme II Hot Start Polymerase (Finnzymes, Espoo, Finland) with primers MangalaF and MangalaR (Nadkarni et al., 2002) according to the producer's instructions. The PCR products were cleaned using ExoSAP-IT (USB Europe GmbH, Staufen, Germany). Sequencing PCR was carried out using the Big Dye Terminator v1.1 Cycle Sequencing Kit (Applied Biosystems Inc., Foster City, CA) according to the manufacturer's instructions, with primer MangalaF. Samples were prepared for sequencing by using the Applied Biosystems BigDye XTerminator 
Purification Kit (Applied Biosystems Inc.) according to the producer's instructions and sequenced by a $3130 x \mathrm{xl}$ Genetic Analyzer (Applied Biosystems Inc.). Acquired sequences (350-450 readable bp) were compared with known sequences using the Ribosomal Database Project (http://rdp.cme.msu.edu/seqmatch/seqmatch_intro. jsp, 06/2010) and bacteria were identified to the genus level and the species level where possible.

\section{Determination of the Microbial Flora: Yeast}

Samples that did not yield PCR products after $16 \mathrm{~S}$ rDNA PCR were by microscopy confirmed to be yeasts. Fresh yeast colonies were picked from PCA plates and subjected to a thermal treatment of $30 \mathrm{~min}$ at $-80^{\circ} \mathrm{C}$ and $60 \mathrm{~min}$ at $65^{\circ} \mathrm{C}$. The $26 \mathrm{~S}$ rDNA PCR was carried out using AmpliTaq Gold Hot Start Polymerase (Roche Diagnostics GmbH, Penzberg, Germany) and primers NL1 (5'-GCA TAT CAA TAA GCG GAG GAA AAG$3^{\prime}$ ) and NL4 (5'-GGT CCG TGT TTC AAG ACG G-3') at the following cycling conditions: $10 \mathrm{~min}$ at $95^{\circ} \mathrm{C}, 38$ cycles of $30 \mathrm{~s}$ at $95^{\circ} \mathrm{C}, 30 \mathrm{~s}$ at $56^{\circ} \mathrm{C}$, and $1 \mathrm{~min}$ at $72^{\circ} \mathrm{C}$, followed by a final extension period of $7 \mathrm{~min}$ at $72^{\circ} \mathrm{C}$. The PCR products were treated as described for bacteria, and sequencing PCR was carried out using primer NL1. Sequencing and database searches were carried out as described for bacteria.

\section{Determination of the Microbial Flora: Mold}

Mold colonies were transferred to malt extract agar (MEA) and potato dextrose agar (PDA; Samson et al., 2010). The inoculated agar media were incubated for 7 $\mathrm{d}$ in the dark at $25 \pm 1^{\circ} \mathrm{C}$ and inspected for genus identification using macro- and microscopic morphological characters. The identified genera were then subcultured on suitable agar plates for species identification. Isolates of Penicillium were plated on MEA, Czapek yeast extract agar (CYA), yeast extract sucrose agar (YES), creatine sucrose agar (CREA), and nitrite sucrose agar $\left(\mathrm{NO}_{2}\right)$, as described in Samson et al. (2010). Other isolates were plated on MEA and PDA. The MEA, CYA, YES, and PDA were incubated in the dark at $25 \pm$ $1^{\circ} \mathrm{C}$, whereas CREA and $\mathrm{NO}_{2}$ at were incubated at 20 $\pm 1^{\circ} \mathrm{C}$ for $7 \mathrm{~d}$.

The mold isolates were identified at species level using a polyphasic approach (Samson and Frisvad, 2004). To differentiate certain species of Penicillium, the Ehrlich test was performed (Samson et al., 2010). All the isolates were identified according to Pitt (1979), Pitt (1999), Samson and Frisvad (2004), and Samson et al. (2010).

Molecular identification by sequencing the internal transcribed spacer (ITS) regions of fungal DNA was performed for some molds when the traditional method of identification was judged to be inefficient. Sequencing was also used for verifying the identification of the dominant mold isolates. The DNA was extracted by the cetyl trimethylammonium bromide (CTAB) DNA extraction protocol (Murray and Thompson, 1980). Briefly, one 4-mm loopful of mold cells from a pure culture was transferred to a 1.5-mL Eppendorf tube containing $600 \mu \mathrm{L}$ of CTAB buffer. The cell mixture was frozen at $-80^{\circ} \mathrm{C}$ for about $20 \mathrm{~min}$, homogenized, and resuspended in $400 \mu \mathrm{L}$ of phenol-chloroform. After centrifuging the mixture at $17,530 \times g$ for $10 \mathrm{~min}$, the upper aqueous phase was transferred to a new Eppendorf-tube. The DNA was then precipitated by adding $300 \mu \mathrm{L}$ of isopropanol by centrifuging at $17,530 \times g$ for another $10 \mathrm{~min}$. The DNA pellet was washed once in $70 \%$ ethanol, resuspended in $100 \mu \mathrm{L}$ of Milli-Q water (EMD Millipore Corp., Billerica, MA) before being used as a template.

The fungus-specific universal primers ITS1 and ITS4 were used to amplify genes encoding the ITS region (White et al., 1990). Primers encoding the $\beta$-tubulin gene, Bt2a and Bt2b (Glass and Donaldson, 1995), were used in addition. Ready-to-go-PCR beads (GE Healthcare, Buckinghamshire, UK) containing PuReTaq polymerase were used and PCR was carried out at the following conditions: $10 \mathrm{~min}$ at $95^{\circ} \mathrm{C}, 38$ cycles of $30 \mathrm{~s}$ at $95^{\circ} \mathrm{C}, 30 \mathrm{~s}$ at $56^{\circ} \mathrm{C}$, and $1 \mathrm{~min}$ at $72^{\circ} \mathrm{C}$, and a final extension at $72^{\circ} \mathrm{C}$ for $7 \mathrm{~min}$. The PCR products were purified by ExoSAP-IT PCR Clean-Up Kit (GE Healthcare). Sequencing was performed using an ABI Prism automated DNA sequencer (Applied Biosystems Inc.). A BigDye Terminator cycle sequencing kit (version 3.1; Applied Biosystems Inc.) was used following the manufacturer's manual on both strands by the same primers. Sequence comparisons were performed using the basic local alignment search tool (BLAST) in GenBank (http://www.ncbi.nlm.nih.gov/blast) after editing and trimming the sequences by BioEdit sequence alignment editor (version 7.0.0; http://www. mbio.ncsu.edu/bioedit/bioedit.html).

\section{Overlay Agar Assay}

A total of 63 microbial isolates (at least 1 of each identified genus; Table 1) were tested individually for inhibitory effects on the growth of $L$. monocytogenes MF3638 [serotype 1/2a; Norwegian Institute of Food, Fisheries and Aquaculture Research (Nofima; Ås, Norway) strain collection], the strain isolated from the Norwegian outbreak in 2007 (Johnsen et al., 2010). Each strain to be tested was cultured in plate count broth (prepared manually as PCA but without the agar) at $25^{\circ} \mathrm{C}$ for $2 \mathrm{~d}$. The PCA plates were inoculated 
Table 1. Overview of strains that were tested for antilisterial activity in an overlay assay ${ }^{1}$

\begin{tabular}{|c|c|c|c|}
\hline Species & Producer & $\begin{array}{c}\text { Sampling } \\
\text { point }^{2}\end{array}$ & MF no. ${ }^{3}$ \\
\hline Achromobacter spp. ${ }^{4}$ & 3 & $\mathrm{RF}$ & 3808 \\
\hline Acidovorax spp. & 4 & $\mathrm{PF}$ & 3771 \\
\hline Acinetobacter spp. & 2 & PD & 3737 \\
\hline Aerococcus spp. & 2 & $\mathrm{I}$ & 3739 \\
\hline Arthrobacter spp. & 1 & I & 3738 \\
\hline Brachybacterium spp. & 2 & PD & 3766 \\
\hline Brevibacterium spp. & 4 & I & 3753 \\
\hline Brevundimonas spp. & 4 & PD & 3743 \\
\hline Carnobacterium maltaromaticum & 1 & $\mathrm{RD}$ & 3744 \\
\hline C. maltaromaticum ${ }^{4}$ & 1 & $\mathrm{RD}$ & 3801 \\
\hline Carnobacterium spp. & 2 & I & 3745 \\
\hline Cellulosimicrobium spp. & 3 & I & 3765 \\
\hline Chryseobacterium spp. & 3 & $\mathrm{RD}$ & 3740 \\
\hline Curvibacter spp. & 4 & $\mathrm{PF}$ & 3768 \\
\hline Debaryomyces hansenii & 5 & RS & 3774 \\
\hline Dermacoccus spp. & 4 & $\mathrm{I}$ & 3752 \\
\hline Devosia spp. & 3 & $\mathrm{RF}$ & 3764 \\
\hline Dyadobacter spp. & 5 & $\mathrm{RF}$ & 3786 \\
\hline Escherichia coli & 2 & $\mathrm{PD}$ & 3733 \\
\hline Enterobacter spp. & 1 & $\mathrm{PF}$ & 3761 \\
\hline Enterococcus casseliflavus & 2 & $\mathrm{PD}$ & 3749 \\
\hline Enterococcus faecalis $^{4}$ & 4 & RS & 3800 \\
\hline Enterococcus spp. & 2 & $\mathrm{PF}$ & 3750 \\
\hline Enterococcus spp. ${ }^{4}$ & 2 & $\mathrm{PF}$ & 3798 \\
\hline Ewingella americana ${ }^{4}$ & 3 & $\mathrm{RF}$ & 3804 \\
\hline Flavobacterium spp. & 1 & $\mathrm{RD}$ & 3751 \\
\hline Geobacillus stearothermophilus & 2 & $\mathrm{PF}$ & 3732 \\
\hline Haloanella spp. & 5 & $\mathrm{RF}$ & 3782 \\
\hline Janibacter spp. & 2 & I & 3763 \\
\hline Janthinobacterium spp. & 3 & $\mathrm{RD}$ & 3734 \\
\hline Kocuria spp. & 4 & $\mathrm{RF}$ & 3731 \\
\hline Lactococcus lactis & 3 & $\mathrm{~S}$ & 3718 \\
\hline Lactococcus lactis ${ }^{4}$ & 5 & $\mathrm{~S}$ & 3792 \\
\hline Leifsonia spp. & 3 & $\mathrm{PF}$ & 3756 \\
\hline Leuconostoc mesenteroides & 5 & $\mathrm{RF}$ & 3783 \\
\hline Leuconostoc pseudomesenteroides ${ }^{4}$ & 5 & $\mathrm{~S}$ & 3793 \\
\hline Listeria spp. & 5 & $\mathrm{RS}$ & 3773 \\
\hline Methylobacterium spp. & 4 & $\mathrm{PF}$ & 3769 \\
\hline Microbacterium gubbeenense ${ }^{4}$ & 3 & RS & 3807 \\
\hline Microbacterium spp. & 3 & $\mathrm{RD}$ & 3724 \\
\hline Microbacterium spp. & 5 & $\mathrm{RF}$ & 3781 \\
\hline Nesterenkonia spp. & 4 & $\mathrm{RF}$ & 3736 \\
\hline Ochrobactrum spp. & 3 & PD & 3757 \\
\hline Paenibacillus spp. & 5 & RS & 3772 \\
\hline Pedobacter spp. & 3 & $\mathrm{PD}$ & 3758 \\
\hline Pelomonas spp. & 1 & $\mathrm{PD}$ & 3762 \\
\hline Plantibacter spp. & 3 & $\mathrm{RF}$ & 3755 \\
\hline Propionibacterium spp. & 4 & $\mathrm{PF}$ & 3770 \\
\hline Pseudomonas putida & 3 & $\mathrm{RF}$ & 3720 \\
\hline Pseudomonas spp. ${ }^{4}$ & 4 & RS & 3796 \\
\hline Psychrobacter spp. & 4 & $\mathrm{RD}$ & 3729 \\
\hline Psychrobacter spp. & 5 & $\mathrm{RF}$ & 3778 \\
\hline Rhodococcus erythropolis & 3 & $\mathrm{RD}$ & 3727 \\
\hline Rothia spp. & 5 & $\mathrm{RF}$ & 3785 \\
\hline Sanguibacter spp. ${ }^{4}$ & 3 & $\mathrm{RF}$ & 3809 \\
\hline Shewanella putrefaciens & 3 & I & 3742 \\
\hline Sphingobacterium spp. & 1 & $\mathrm{RF}$ & 3754 \\
\hline Sphingomonas spp. & 2 & I & 3759 \\
\hline Staphylococcus equorum & 2 & I & 3723 \\
\hline
\end{tabular}


Table 1 (Continued). Overview of strains that were tested for antilisterial activity in an overlay assay ${ }^{1}$

\begin{tabular}{lccc}
\hline Species & Producer & $\begin{array}{c}\text { Sampling } \\
\text { point }^{2}\end{array}$ & MF no. $^{3}$ \\
\hline Staphylococcus spp. & 4 & $\mathrm{RS}$ & 3722 \\
Stenotrophomonas maltophilia & 4 & $\mathrm{PD}$ & 3805 \\
Streptococcus spp. & 4 & $\mathrm{PD}$ & 3735 \\
Tsukamurella spp. & 2 & $\mathrm{I}$ & 3746 \\
\hline
\end{tabular}

${ }^{1}$ Strains in bold characters showed slight inhibition (zones of 2 to $3 \mathrm{~mm}$ ) of Listeria monocytogenes MF3638. ${ }^{2} \mathrm{RF}=$ floor in the ripening room; $\mathrm{PF}=$ floor in the production room; $\mathrm{PD}=$ drain in the production room; $\mathrm{I}=$ rubber insulation around doors; $\mathrm{RD}=$ drain in the ripening room; $\mathrm{RS}=$ ripening room shelves; $\mathrm{S}=$ salt brines.

${ }^{3} \mathrm{MF}$ no. refers to the Norwegian Institute of Food, Fisheries and Aquaculture Research (Nofima; Ås, Norway) strain collection.

${ }^{4}$ Strains isolated from Listeria-selective enrichment media, not directly from swab platings.

with spots of $1 \mu \mathrm{L}$ each of the strains to be tested and incubated for $48 \mathrm{~h}$ at $25^{\circ} \mathrm{C}$. An overnight culture of L. monocytogenes in plate count broth $(300 \mu \mathrm{L})$ was mixed with $8 \mathrm{~mL}$ of PCA soft agar. The mixture was deposited on the spotted plates and the plates were incubated at $37^{\circ} \mathrm{C}$ for $24 \mathrm{~h}$ before measuring the inhibition zone.

\section{Spot-on-Lawn Assay}

The method was adapted from Larsen and Knøchel (1997). The PCA plates were inoculated with a diluted overnight culture of L. monocytogenes $(500 \mu \mathrm{L}$; approximately $10^{7} \mathrm{cfu} /$ plate) and allowed to dry on a sterile workbench for $15 \mathrm{~min}$. Overnight cultures $(5 \mu \mathrm{L})$ of the strains to be tested, as described for the overlay assay, were spotted onto this layer of $L$. monocytogenes and the plates were incubated at $20^{\circ} \mathrm{C}$ for $3 \mathrm{~d}$ before measuring the inhibition zone.

\section{Co-Culture Biofilm Assay}

The method was adapted from Carpentier and Chassaing (2004). Pressed ceramic stoneware tiles (catalog no. 1050/12; Höganäs Céramique France SA, Thouarésur-Loire, France) were cut to pieces $(2.5 \times 4 \mathrm{~cm})$ and a wall of transparent bathroom silicone (silicone bâtiment translucide; Fischer SAS., Strasbourg, France) was applied, resulting in a working surface of approximately $7.5 \mathrm{~cm}^{2}$. Five bacterial isolates from the production sites were selected for the experiments: Lactococcus lactis (MF3719), Pseudomonas putida (MF3721), Staphylococcus equorum (MF3723), Rhodococcus spp. (MF3727), and Psychrobacter spp. (MF3729). With the exception of the Pseudomonas strain, the isolates belonged to genera or species found in at least 4 of the 5 visited sites and were part of the dominating flora in the storage environments.
The strains were cultured in brain heart infusion (BHI; Oxoid Ltd.) for $3 \mathrm{~d}$ at $20^{\circ} \mathrm{C}$, with the exception of L. monocytogenes, which was cultured for $24 \mathrm{~h}$ at $37^{\circ} \mathrm{C}$. All bacterial suspensions used in the biofilm assay were made by diluting the respective cultures in $1 \%$ skim milk (Merck) to a bacterial concentration of approximately $10^{6} \mathrm{cfu} / \mathrm{mL}$. One milliliter of bacterial test suspension of each of the isolates from cheese environments was added to 6 to 8 coupons and left at $12^{\circ} \mathrm{C}$ for $3 \mathrm{~h}$ for cell attachment. The bacterial suspension was removed carefully by pipetting and the coupons were stored at $12^{\circ} \mathrm{C}$ and $98 \%$ relative humidity $(\mathbf{R H})$ for $3 \mathrm{~d}$ and rinsed carefully by pipetting sterile water $(3 \times 25 \mathrm{~mL})$ on the coupons to remove unattached cells. After rinsing, $1 \mathrm{~mL}$ of freshly prepared L. monocytogenes suspension (also $10^{6} \mathrm{cfu} / \mathrm{mL}$ in $1 \%$ skim milk) was added to the coupon and left at $12^{\circ} \mathrm{C}$ for $3 \mathrm{~h}$. The remaining suspension was removed carefully by pipetting to remove unattached cells and the coupons were stored at $12^{\circ} \mathrm{C}$ and $98 \% \mathrm{RH}$ for $9 \mathrm{~d}$. On the last day, coupons were again rinsed with $3 \times$ $25 \mathrm{~mL}$ of sterile water to remove unattached cells and swabbed with a cotton swab. The swab was stored in 1 $\mathrm{mL}$ of peptone water and vortexed vigorously to remove cells from the swab. Suitable dilutions of the peptone water were plated on Brilliance Listeria Agar (Oxoid Ltd.) and BHI to obtain L. monocytogenes numbers and total bacterial numbers, respectively. The experiment was carried out 3 times with freshly prepared cultures each time.

\section{RESULTS}

\section{Characterization of the Microbial Background Flora}

Listeria monocytogenes was not found in any of the production sites. Total bacterial counts generally appeared to be higher in the ripening room than in the production room $\left(1-4 \log _{10} \mathrm{cfu} / \mathrm{cm}^{2}\right)$ and higher in drains than on floors $\left(1-2 \log _{10}\right)$. Direct quantita- 
tive comparisons were, however, difficult due to uneven surfaces, especially in drains, that made it hard to standardize the sampling areas. No bacteria were detected on the ready-to-use plastic cheese molds. A total of 1,314 isolates were identified. The complete results of the microbial survey are presented in Supplemental Table S1 (available online at http://dx.doi.org/10.3168/ jds.2012-6395). Fifty-five bacterial genera, 1 species of yeast (Debaryomyces hansenii), and 6 species of mold (Penicillium camemberti, Penicillium roqueforti, Penicillium commune, Penicillium echinulatum, Cladosporium cladosporioides, and Lecanicillium lecanii) were isolated. Only 4 of the bacterial genera (Lactococcus spp., Staphylococcus spp., Microbacterium spp., and Psychrobacter spp.) were found in all 5 sites, but more than $80 \%$ of the total bacteria found comprised 11 genera (Pseudomonas spp., Rhodococcus spp., Kocuria spp., Geobacillus spp., Escherichia coli, Brevibacterium spp., and Janthinobacterium spp. in addition to the aforementioned 4). Thirty-two genera were found in single facilities only. Results showed great variations in the microbial composition both between and within all sampled production sites. Figures 1 and 2 illustrate the differences in microbial background flora at corresponding sampling points at various producers. Within most production sites, the dominating bacterial genera were similar in drains and on corresponding floors, as illustrated in Figure 3. In general, the background flora was less diverse in the salt brine and on cheese storage surfaces than in other sampling sites. The material of the cheese storage surfaces did not appear to have any influence on the bacterial composition, as no significant differences were found between wooden and synthetic shelves. Also, no significant differences were observed between metal and stoneware drains.

\section{Effect of Single Strains on the Growth of Listeria monocytogenes}

A total of 63 strains, at least 1 of each bacterial and yeast species or genus isolated from the production sites, were tested for antilisterial activity in an overlay assay and in a spot-on-lawn assay. Twenty-four out of the 63 tested strains showed slight inhibition of the growth of L. monocytogenes (Table 1 ). However, although a known bacteriocin producer (Lactobacillus plantarum Alc01; Danisco, Copenhagen, Denmark) yielded inhibition zones with a radius of 1.2 to $1.5 \mathrm{~cm}$, none of the tested mold, yeast, or bacteria strains yielded inhibition zones with a radius larger than 2 to $3 \mathrm{~mm}$, indicating that the inhibitory effect was comparably small.

\section{Co-Culture Biofilms}

Listeria monocytogenes was cultured on ceramic tiles that had previously been inoculated with a strain of $L c$.

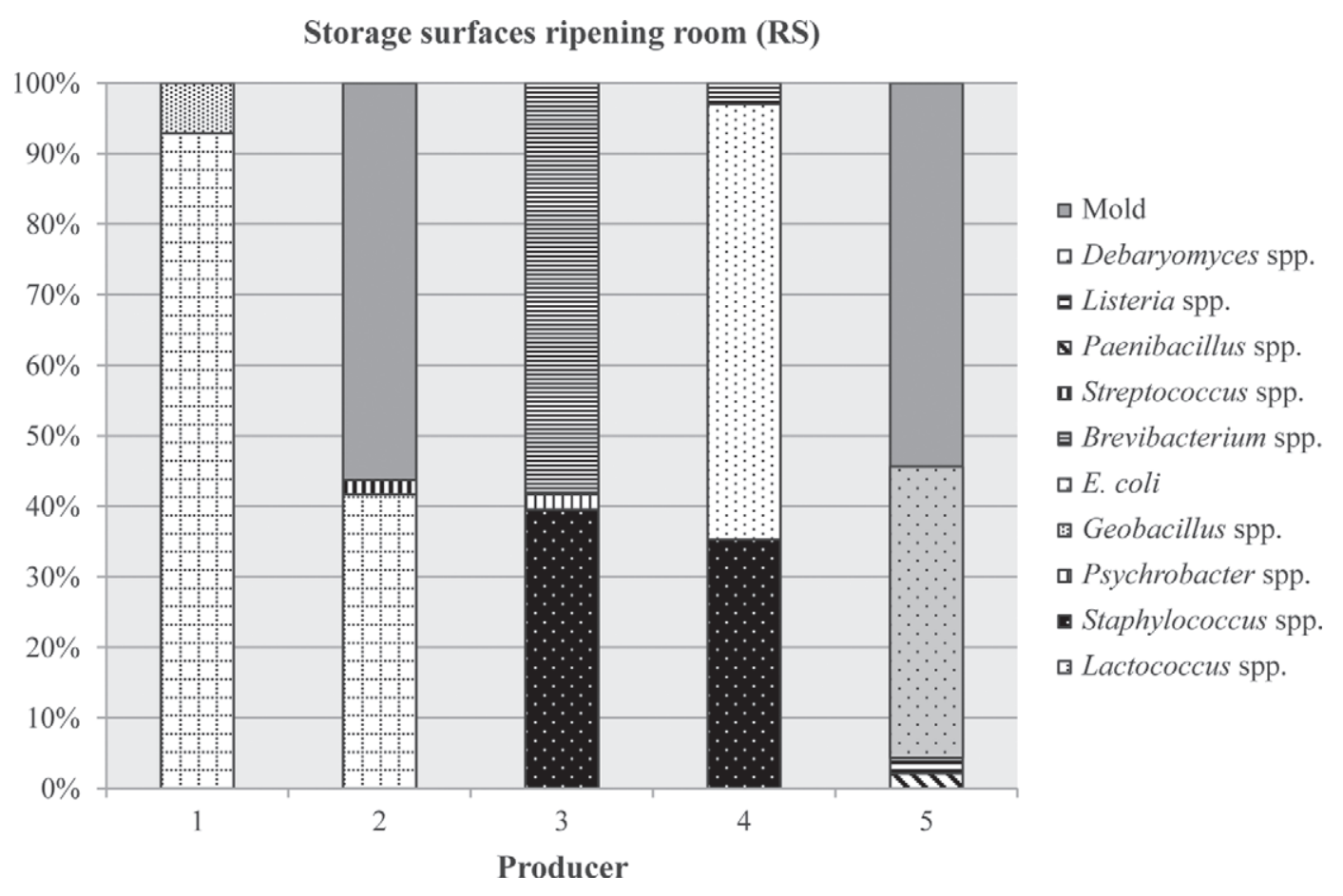

Figure 1. Microbial background flora profile on the storage surfaces in contact with cheese in the storage rooms of 5 different producers $[\mathrm{n}$ $=14($ producer 1$), \mathrm{n}=48($ producer 2$), \mathrm{n}=48($ producer 3$), \mathrm{n}=34$ (producer 4$), \mathrm{n}=46$ (producer 5$)]$. E. coli = Escherichia coli. 
Floor ripening room (RF)

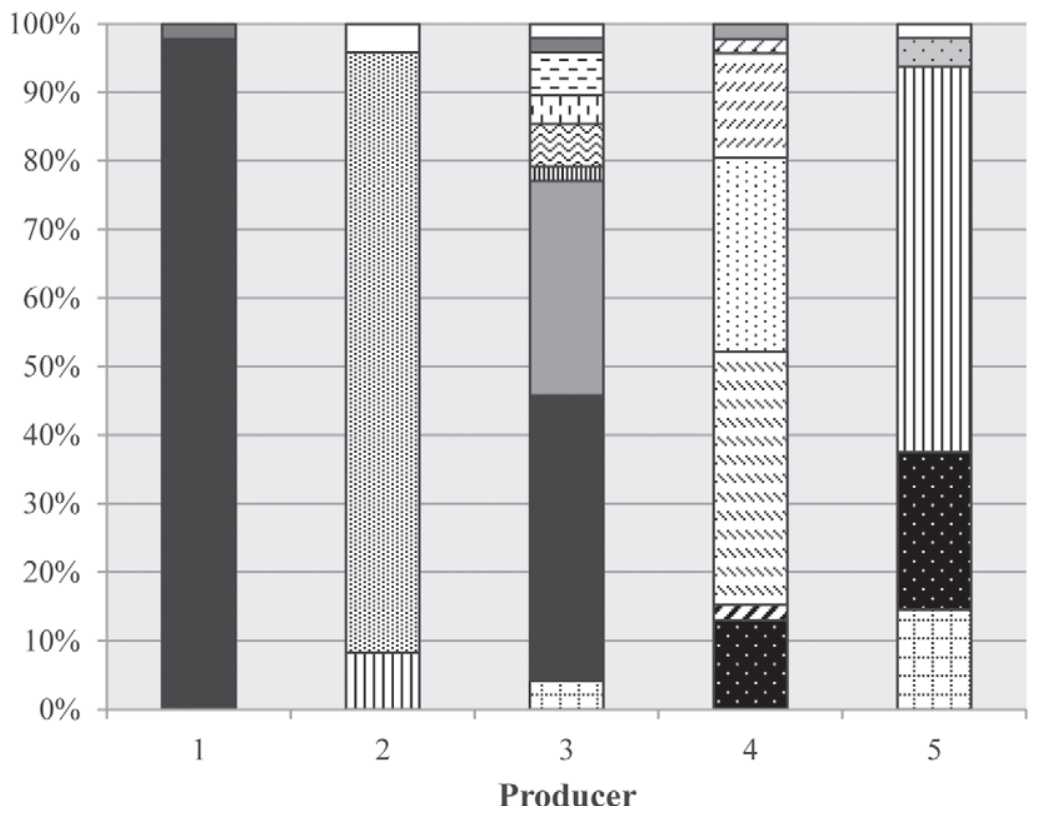

$\square$ Not determined

$\square$ Mold

๑ Debaryomyces spp.

- Devosia spp.

口 Brachybacterium spp.

- Plantibacter spp.

- Sphingobacterium spp.

- Pedobacter spp.

\& Brevundimonas spp.

m Chryseobacterium spp.

- Nesterenkonia spp.

$\square$ Janthinobacterium spp.

由. E. coli

Geobacillus spp.

口 Kocuria spp.

口 Psychrobacter spp.

- Microbacterium spp.

- Staphylococcus spp.

- Pseudomonas spp.

$\checkmark$ Lactococcus spp.

Figure 2. Microbial background flora profile on the floor of the storage rooms of 5 different producers $[\mathrm{n}=46$ (producer 1$), \mathrm{n}=24($ producer $2), \mathrm{n}=48$ (producer 3$), \mathrm{n}=46$ (producer 4$), \mathrm{n}=48$ (producer 5$)]$. E. coli $=$ Escherichia coli.

Producer 1

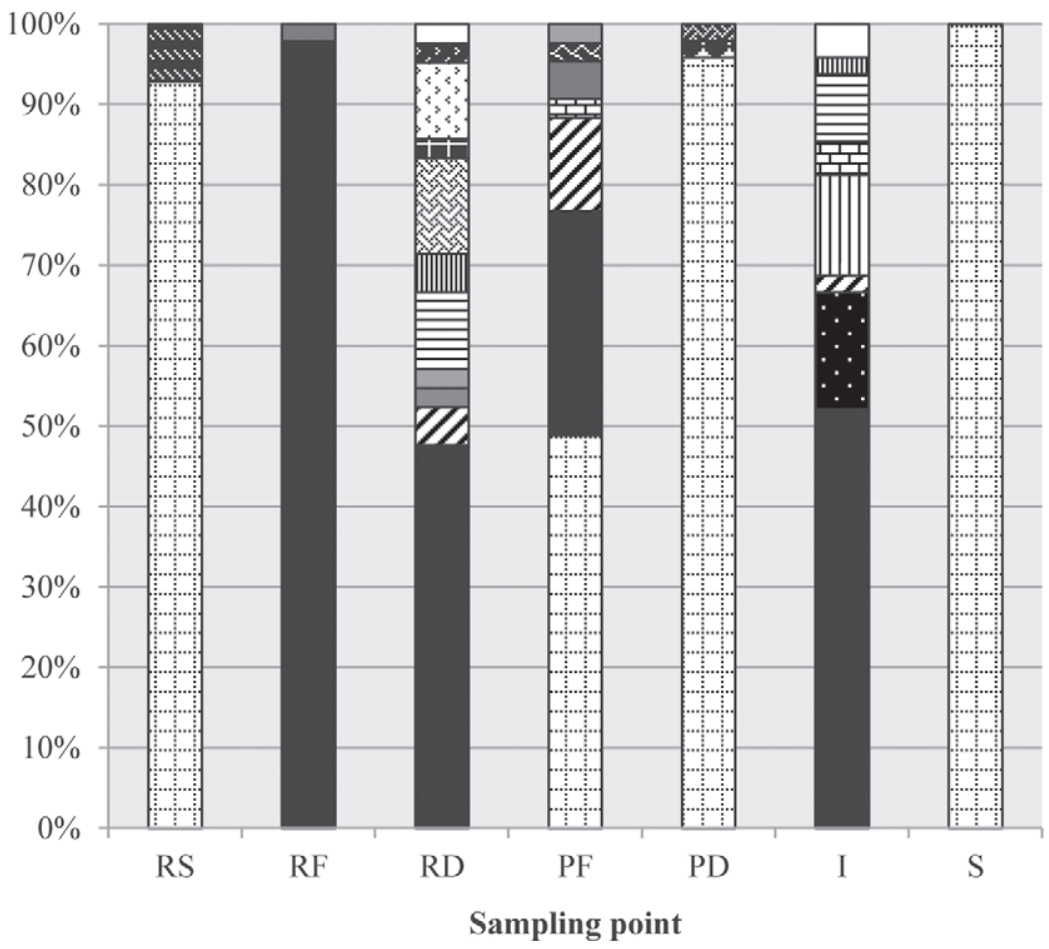

$\square$ Not determined

口 Mold

s Pelomonas spp.

Enterobacter spp.

口 Sphingobacterium spp.

- Flavobacterium spp.

Enterococcus spp.

घ Carnobacterium spp.

- Brevundimonas spp.

$\checkmark$ Stenotrophomonas spp.

m Chryseobacterium spp.

口 Arthrobacter spp.

a Acinetobacter spp.

$\square$ Janthinobacterium spp.

Geobacillus spp.

- Psychrobacter spp.

口 Rhodococcus spp.

口 Microbacterium spp.

- Staphylococcus spp.

- Pseudomonas spp.

口 Lactococcus spp.

Figure 3. Microbial background flora profile at various sampling points at producer 1 . Sampling points were as follows: RS $=$ ripening room shelves, $\mathrm{RF}=$ floor in the ripening room, $\mathrm{RD}=$ drain in the ripening room, $\mathrm{PF}=$ floor in the production room, $\mathrm{PD}=$ drain in the production room, $\mathrm{I}=$ rubber insulation around doors, $\mathrm{S}=$ salt brines $[\mathrm{n}=14(\mathrm{RS}), \mathrm{n}=46(\mathrm{RF}), \mathrm{n}=42(\mathrm{RD}), \mathrm{n}=43(\mathrm{PF}), \mathrm{n}=48(\mathrm{PD}), \mathrm{n}=48(\mathrm{I}), \mathrm{n}$ $=24(\mathrm{~S})]$. 
lactis, Pseudomonas putida, Staphylococcus equorum, Rhodococcus spp., or Psychrobacter spp. Test strains reached concentrations between $3.7 \times 10^{4}$ and $1.1 \times 10^{5}$ $\mathrm{cfu} / \mathrm{cm}^{2}$ before L. monocytogenes was added to the coupons. The initial L. monocytogenes concentration after the remaining suspension had been removed was 2 to 3 $\times 10^{3} \mathrm{cfu} / \mathrm{cm}^{2}$. Results showed that L. monocytogenes grew to concentrations of between $3.5 \times 10^{3}$ and $6.7 \times$ $10^{4} \mathrm{cfu} / \mathrm{cm}^{2}$ within $9 \mathrm{~d}$ of storage, regardless whether it was cultured alone or together with one of the tested single strains.

\section{DISCUSSION}

The microbial background flora was investigated at 5 small-scale cheese production sites that were spread across Norway. The aim of the study was to determine if cheese production environments have a common background flora and whether this flora can potentially affect survival, growth, or surface colonization of $L$. monocytogenes. Of the 55 different bacterial genera and genera that were isolated from the production sites, only 4 were present in all 5 sites, whereas 32 were only found in 1 of the sites. It is hence not likely that the latter occur widely as a regular part of the background flora in cheese-producing environments. Because $L c$. lactis is commonly used as a starter culture, its presence was expected.

Plate count agar was used as the growth medium, as it contains casein and has been shown to support the growth of most dairy-related bacteria (Bore and Langsrud, 2005). Still, this study was limited to culturable cells. Unculturable cells may have effects on the growth and survival of L. monocytogenes that cannot be accounted for by this study (Quigley et al., 2011). Among the 11 bacterial genera that comprised more than $80 \%$ of all bacteria isolated, 7 were isolated from at least 3 farms. Notably, more than $90 \%$ of all isolated $E$. coli were found at the one farm that used unpasteurized milk for cheese production. Also, $44 \%$ of all Staphylococcus isolates and $71 \%$ of all Kocuria isolates were found at this farm. As only 1 of the included farms used unpasteurized milk, it was not possible to conclude that the presence of these bacteria is common at this kind of producer. It is, however, possible that the source of these bacteria was the raw milk, as these types of bacteria have been reported to be present in raw milk (Fricker et al., 2011; Van Kessel et al., 2011). Lactococcus lactis, which was frequently found at most sampling points at all sites using pasteurized milk, was found only in the brine at the site using unpasteurized milk, but not in any other environmental sites.
As expected, the greatest diversity in the flora was found in places where cleaning was less thorough. This included drains and rubber insulations of doors where 35 and 26 different bacterial genera were found, respectively. The smallest diversity in the bacterial flora was found in the brines, where only 6 different bacterial species or genera (Lc. lactis, Staphylococcus spp., Psychrobacter spp., Microbacterium spp., Geobacillus stearothermophilus, and Leuconostoc pseudomesenteroides) were present and on the storage shelves, where 9 bacterial species or genera could be found in addition to 1 species of yeast and 6 species of mold.

The small variation of the bacterial composition in the brines was most likely caused by the harsh conditions ( $\mathrm{pH}$ ranging from 4.5 to 6.0 and salt concentrations between 15 and $27 \%$ ) that did not allow for growth of many of microorganisms. Staphylococci are known to tolerate high salt concentrations (Bergdoll, 1989), as well as strains of Microbacterium gubbeenense (Bockelmann et al., 2003) and various Leuconostoc strains (Nieto-Arribas et al., 2010). Some Psychrobacter species have been related to survival at low temperatures and low water activity, corresponding to high salt concentrations (Ponder et al., 2008). However, none of these species are expected to grow at salt concentrations above $15 \%$. With the exception of $L$. pseudomesenteroides, all strains that were found in the brines were also found in the surrounding environment. It is hence likely that these strains were also present on the product, and the brines are replenished with these bacteria from the cheese over time. Lactococcus lactis dominated the flora in 4 of the 5 brines. In the fifth brine, Staphylococcus spp. dominated. Although the salt concentration in this brine was within the range of the other 4 brines, measurements showed that the brine dominated by Staphylococcus spp. had the highest $\mathrm{pH}$ value $(6.01$, whereas the others ranged from 4.54 to 5.52). This may be the reason for why Staphylococcus spp. were able to survive and compete with the lactic acid bacteria.

Mariani et al. (2007) isolated bacteria from wooden shelves and found leuconostocs, enterococci, pseudomonads, and lactobacilli, in addition to staphylococci, at 8 out of 8 tested farms in France. In an Italian study, streptococci, lactobacilli, enterococci, and lactococci were found in 4 out of 4 tested wooden Tina vats (Lortal et al., 2009). In our study, lactococci, streptococci, staphylococci, and pseudomonads were also found on cheese contact surfaces, whereas the other mentioned species were not detected. In addition, other genera, including Geobacillus spp., Brevibacterium spp., and E. coli were found in high proportions at single farms. This shows that the flora on contact surfaces varies between 
sampling locations. This may be due to environmental factors and may also reflect variations in the flora on the surface of the product in contact with the storage surface.

Penicillium camemberti and $P$. roqueforti are commonly used as starter cultures, and are hence expected to be found in cheese production environments. Penicillium commune and C. cladosporioides are common indoor fungi in temperate regions (Samson et al., 2010). Penicillium commune, the wild form of P. camemberti, and $P$. echinulatum both belong to the associated flora of cheeses (Samson and Frisvad, 2004). They are hence not surprising to find in such environments. Penicillium echinulatum is also associated with wood and wood products (Samson and Frisvad, 2004), and wooden storage shelves for cheeses are consequently perfect environment for this species. Cladosporium cladosporioides grows very well in environments with fluctuating temperatures and is associated with water-damaged wood (Samson et al., 2010) and is commonly found in storage rooms for food and feed. Lecanicillium lecanii is considered to be pathogenic to insects and may be a contamination from insects in the production facility.

It is believed that the presence of an active microflora in the food-processing environment may inhibit the growth or reduce the total number of pathogenic bacteria, including L. monocytogenes, both in complex biofilms (Guillier et al., 2008; Mariani et al., 2011) and as single strains (Zhao et al., 2004). However, other studies have shown that the presence of other bacteria may increase the ability of Listeria to establish itself on surfaces (Leriche and Carpentier, 2000; Bremer et al., 2001; Carpentier and Chassaing, 2004; Rieu et al., 2008). The current study investigated the effects of microbial strains that were most commonly isolated from the production environment of small cheese farms on the growth of L. monocytogenes. Only slight inhibition compared with a known inhibiting strain was observed in an overlay assay testing 63 bacterial and yeast isolates. None of the 5 tested bacterial strains showed conclusive inhibition of $L$. monocytogenes when cultivated together on a ceramic surface at conditions relevant for cheese ripening (milk-based soil, $12^{\circ} \mathrm{C}$, and $98 \%$ RH). Previous studies have indicated that biofilm formation on surfaces may be reduced in the presence of nisin-producing Lc. lactis (Leriche et al., 1999; Zhao et al., 2004) or P. putida (Carpentier and Chassaing, 2004; Saá Ibusquiza et al., 2012) and by some, but not all Staphylococcus spp. (Leriche and Carpentier, 2000; Carpentier and Chassaing, 2004; Rieu et al., 2008; Zameer et al., 2010). The effect is, however, highly dependent on the experimental conditions such as strains, temperature, and inoculum concentration (Leriche et al. 1999; Zhao et al., 2004; Saá Ibusquiza et al., 2012) and using relevant strains and conditions mimicking the production environment in question is, therefore, crucial. It must also be taken into account that the current study was limited to the effect of single strains from the background flora. It does not consider the possibility of several bacterial strains acting together to inhibit the growth of Listeria. Studies exist that have shown that complex bacterial mixtures may increase the attachment of L. monocytogenes, whereas single strains do not (Guðbjörnsdóttir et al., 2005). This may, however, be due to nutrient consumption by competing microflora and not the production of inhibitory substances (Guillier et al., 2008).

\section{CONCLUSIONS}

This study shows that no common background flora exists in small-scale cheese production environments. Only 4 of the isolated species could be found at all 5 production sites and none of these could be found at all sampling points within the farms. Isolates from these species did not show significant antilisterial activity in biofilm and growth-inhibition assays. Additional selected isolates comprising all bacterial species identified among the 5 producers showed only slight growth inhibitory activity to Listeria. This study also shows that species and strains with significant activity against $L$. monocytogenes growth and survival are not widespread in small-scale cheese production facilities. It was hence not possible to demonstrate that the environmental background flora of small-scale cheese production sites provides a significant contribution for controlling growth and survival of L. monocytogenes in the plants.

\section{ACKNOWLEDGMENTS}

The work was funded by the Foundation for Research Levy on Agricultural Products (Oslo, Norway) and the Agricultural Agreement Research Fund. Our thanks go to all cheese producers who contributed to this work. We also thank Birgitta Baardsen (Nofima, Ås, Norway) for her work with the overlay and spot-on-lawn experiments and Therese Hagtvedt (Nofima) for help with sampling and constructive discussions.

\section{REFERENCES}

Bell, C., and A. Kyriakides. 2005. Outbreaks: Causes and lessons to be learnt. Pages 28-31 in Listeria: A Practical Approach to the Organism and its Control in Foods. 2nd ed. Blackwell Publishing Ltd., Oxford, UK.

Bemrah, N., M. Sanaa, M. H. Cassin, M. W. Griffiths, and O. Cerf. 1998. Quantitative risk assessment of human listeriosis from consumption of soft cheese made from milk. Prev. Vet. Med. 37:129 145 . 
Bergdoll, M. S. 1989. Staphylococcus aureus. Pages 463-523 in Foodborne Bacterial Pathogens. M. P. Doyle, ed. Marcel Dekker Inc., New York, NY.

Bille, J., D. S. Blanc, H. Schmid, K. Boubaker, A. Baumgartner, H. H. Siegrist, M. L. Tritten, R. Lienhard, D. Berner, R. Anderau, M. Treboux, J. M. Ducommun, R. Malinverni, D. Genné, P. H. Erard, and U. Waespi. 2006. Outbreak of human listeriosis associated with tomme cheese in northwest Switzerland, 2005. Euro Surveill. 11:91-93.

Bockelmann, V., P. Willems, J. Rademaker, W. Noordman, and K. J. Heller. 2003. Cultures for surface ripening of smeared soft cheese. Kieler Milchwirtschaftliche Forschungsberichte 55:277-299.

Bore, E., and S. Langsrud. 2005. Characterization of micro-organisms isolated from dairy industry after cleaning and fogging disinfection with alkyl amine and peracetic acid. J. Appl. Microbiol. 98:96-105.

Bremer, P. J., I. Monk, and C. M. Osborne. 2001. Survival of Listeria monocytogenes attached to stainless steel surfaces in the presence or absence of Flavobacterium spp. J. Food Prot. 64:1369-1376.

Carpentier, B., and D. Chassaing. 2004. Interactions in biofilms between Listeria monocytogenes and resident microorganisms from food industry premises. Int. J. Food Microbiol. 97:111-122.

Carrique-Mas, J. J., I. Hökeberg, Y. Andersson, M. Arneborn, W. Tham, M.-L. Danielsson-Tham, B. Osterman, M. Leffler, M Steen, E. Eriksson, G. Hedin, and J. Giesecke. 2003. Febrile gastroenteritis after eating on-farm manufactured fresh cheese-An outbreak of listeriosis? Epidemiol. Infect. 130:79-86.

Di Bonaventura, G., R. Piccolomini, D. Paludi, V. D'Orio, A. Vergara, M. Conter, and A. Ianieri. 2008. Influence of temperature on biofilm formation by Listeria monocytogenes on various food-contact surfaces: Relationship with motility and cell surface hydrophobicity. J. Appl. Microbiol. 104:1552-1561.

Fretz, R., J. Pichler, U. Sagel, P. Much, W. Ruppitsch, A. T. Pietzka, A. Stöger, S. Huhulescu, S. Heuberger, G. Appl, D. Werber, K. Stark, R. Prager, A. Flieger, R. Karpíšková, G. Pfaff, and F. Allerberger. 2010. Update: Multinational listeriosis outbreak due to 'Quargel', a sour milk curd cheese, caused by two different $L$. monocytogenes serotype 1/2a strains, 2009-2010. Euro Surveill. 15:pii:19543.

Fricker, M., B. Skånseng, K. Rudi, B. Stessl, and M. Ehling-Schulz. 2011. Shift from farm to dairy tank milk microbiota revealed by a polyphasic approach is independent from geographical origin. Int. J. Food Microbiol. 145:S24-S30.

Gaulin, C., D. Ramsay, and S. Bekal. 2012. Widespread listeriosis outbreak attributable to pasteurized cheese, which led to extensive cross-contamination affecting cheese retailers, Quebec, Canada 2008. J. Food Prot. 75:71-78.

Gaulin, C., D. Ramsay, L. Ringuette, and J. Ismaill. 2003. First documented outbreak of Listeria monocytogenes in Quebec, 2002. Can. Commun. Dis. Rep. 29:181-186.

Glass, N. L., and G. C. Donaldson. 1995. Development of primer sets designed for use with the PCR to amplify conserved genes from filamentous ascomycetes. Appl. Environ. Microbiol. 61:1323-1330.

Guð̋björnsdóttir, B.. H. Einarsson, and G. Thorkelsson. 2005. Microbial adhesion to processing lines for fish fillets and cooked shrimp: Influence of stainless steel surface finish and presence of gramnegative bacteria on the attachment of Listeria monocytogenes. Food Technol. Biotechnol. 43:55-61.

Guillier, L., V. Stahl, B. Hezard, E. Notz, and R. Briandet. 2008. Modelling the competitive growth between Listeria monocytogenes and biofilm microflora of smear cheese wooden shelves. Int. J. Food Microbiol. 128:51-57.

Johnsen, B. O., E. Lingaas, D. Torfoss, E. H. Strøm, and I. Nordøy. 2010. A large outbreak of Listeria monocytogenes infection with short incubation period in a tertiary care hospital. J. Infect. 61:465-470.

Lado, B. H., and A. E. Yousef. 2007. Characteristics of Listeria monocytogenes important to food processes. Pages 157-213 in Listeria, Listeriosis, and Food Safety. E. T. Ryser and E. H. Marth, ed. CRC Press.
Langsrud, S., T. Møretrø, and E. Heir. 2012. Bacteria in the food production environment. Food Sci. Technol. 26:26-30.

Larsen, A. G., and S. Knøchel. 1997. Antimicrobial activity of food-related Penicillium sp. against pathogenic bacteria in laboratory media and a cheese model system. J. Appl. Microbiol. 83:111-119.

Larson, A. E., E. A. Johnson, and J. H. Nelson. 1999. Survival of Listeria monocytogenes in commercial cheese brines. J. Dairy Sci. 82:1860-1868.

Leriche, V., and B. Carpentier. 2000. Limitation of adhesion and growth of Listeria monocytogenes on stainless steel surfaces by Staphylococcus sciuri biofilms. J. Appl. Microbiol. 88:594-605.

Leriche, V., D. Chassaing, and B. Carpentier. 1999. Behaviour of $L$. monocytogenes in an artificially made biofilm of a nisin-producing strain of Lactococcus lactis. Int. J. Food Microbiol. 51:169-182.

Licitra, G., J. C. Ogier, S. Parayre, C. Pediliggieri, T. M. Carnemolla, H. Falentin, M. N. Madec, S. Carpino, and S. Lortal. 2007. Variability of bacterial biofilms of the "Tina" wood vats used in the Ragusano cheese-making process. Appl. Environ. Microbiol. 73:6980-6987.

Lortal, S., A. Di Blasi, M. N. Madec, C. Pediliggieri, L. Tuminello, G. Tanguy, J. Fauquant, Y. Lecuona, P. Campo, S. Carpino, and G. Licitra. 2009. Tina wooden vat biofilm: A safe and highly efficient lactic acid bacteria delivering system in PDO Ragusano cheese making. Int. J. Food Microbiol. 132:1-8.

Makino, S. I., K. Kawamoto, K. Takeshi, Y. Okada, A. Yamasaki, S. Yamamoto, and S. Igimi. 2005. An outbreak of food-borne listeriosis due to cheese in Japan, during 2001. Int. J. Food Microbiol. 104:189-196.

Mariani, C., R. Briandet, J.-F. Chamba, E. Notz, A. Carnet-Pantiez, R. N. Eyoug, and N. Oulahal. 2007. Biofilm ecology of wooden shelves used in ripening the French raw milk smear cheese Reblochon de Savoie. J. Dairy Sci. 90:1653-1661.

Mariani, C., N. Oulahal, J.-F. Chamba, F. Dubois-Brissonnet, E. Notz, and R. Briandet. 2011. Inhibition of Listeria monocytogenes by resident biofilms present on wooden shelves used for cheese ripening. Food Contr. 22:1357-1362.

Murray, M. G., and W. F. Thompson. 1980. Rapid isolation of high molecular weight plant DNA . Nucleic Acids Res. 8:4321-4325.

Nadkarni, M. A., F. E. Martin, N. A. Jacques, and N. Hunter. 2002. Determination of bacterial load by real-time PCR using a broadrange (universal) probe and primers set. Microbiology 148:257266.

Nieto-Arribas, P., S. Seseña, J. M. Poveda, L. Palop, and L. Cabezas. 2010. Genotypic and technological characterization of Leuconostoc isolates to be used as adjunct starters in Manchego cheese manufacture. Food Microbiol. 27:85-93.

Pitt, J. I. 1979. The Genus Penicillium and its Teleomorphic States Eupenicillium and Talaromyces. Academic Press, London, UK.

Pitt, J. I. 1999. Fungi and food spoilage. 2nd ed. Aspen Publishers Inc., Frederick, MD

Ponder, M. A., M. F. Thomashow, and J. M. Tiedje. 2008. Metabolic activity of Siberian permafrost isolates, Psychrobacter arcticus and Exiguobacterium sibiricum, at low water activities. Extremophiles 12:481-490.

Quigley, L., O. O'Sullivan, T. P. Beresford, R. P. Ross, G. F. Fitzgerald, and P. D. Cotter. 2011. Molecular approaches to analysing the microbial composition of raw milk and raw milk cheese. Int. J. Food Microbiol. 150:81-94

Retureau, É., C. Callon, R. Didienne, and M.-C. Montel. 2010. Is microbial diversity an asset for inhibiting Listeria monocytogenes in raw milk cheeses? Dairy Sci. Technol. 90:375-398.

Rieu, A., J.-P. Lemaître, J. Guzzo, and P. Piveteau. 2008. Interactions in dual species biofilms between Listeria monocytogenes EGD-e and several strains of Staphylococcus aureus. Int. J. Food Microbiol. 126:76-82.

Romanova, N., S. Favrin, and M. W. Griffiths. 2002. Sensitivity of Listeria monocytogenes to sanitizers used in the meat processing industry. Appl. Environ. Microbiol. 68:6405-6409.

Saá Ibusquiza, P., J. J. R. Herrera, D. Vázquez-Sánchez, and M. L. Cabo. 2012. Adherence kinetics, resistance to benzalkonium chlo- 
ride and microscopic analysis of mixed biofilms formed by Listeria monocytogenes and Pseudomonas putida. Food Contr. 25:202-210.

Samson, R. A., and J. C. Frisvad. 2004. Penicillium subgenus Penicillium: New taxonomic schemes and mycotoxins and other extrolites. Page 257 in Studies in Mycology. Centraalbureau voor Schimmelcultures, Utrecht, the Netherlands.

Samson, R. A., J. Houbraken, U. Thrane, J. C. Frisvad, and B. Andersen. 2010. Food and Indoor Fungi. Centraalbureau voor Schimmelcultures, Utrecht, the Netherlands.

Schvartzman, M. S., A. Maffre, F. Tenenhaus-Aziza, M. Sanaa, F. Butler, and K. Jordan. 2011. Modelling the fate of Listeria monocytogenes during manufacture and ripening of smeared cheese made with pasteurised or raw milk. Int. J. Food Microbiol. 145(Suppl. 1):S31-S38.

Skånseng, B., M. Kaldhusdal, and K. Rudi. 2006. Comparison of chicken gut colonisation by the pathogens Campylobacter jejuni and Clostridium perfringens by real-time quantitative PCR. Mol. Cell. Probes 20:269-279.

Swaminathan, B., and P. Gerner-Smidt. 2007. The epidemiology of human listeriosis. Microbes Infect. 9:1236-1243.
Van Kessel, J. A. S., J. S. Karns, J. E. Lombard, and C. A. Kopral. 2011. Prevalence of Salmonella enterica, Listeria monocytogenes, and Escherichia coli virulence factors in bulk tank milk and in-line filters from US dairies. J. Food Prot. 74:759-768.

Vít, M., R. Olejník, J. Dlhý, R. Karpišková, J. Částcová, V. Príkazský, M. Príkazská, Č. Beneš, and P. Petráš. 2007. Outbreak of listeriosis in the Czech Republic, late 2006-Preliminary report. Euro Surveill. 12: E070208.1.

White, T. J., T. Burns, S. Lee, and J. Taylor. 1990. Amplification and direct sequencing of fungal ribosomal RNA genes for phylogenetics. Pages 315-322 in PCR Protocols: A Guide to Methods and Applications. M. A. Innis, D. H. Gelfand, J. J. Sninsky, and T. J. White, ed. Academic Press Inc., New York, NY.

Zameer, F., J. Kreft, and S. Gopal. 2010. Interaction of Listeria monocytogenes and Staphylococcus epidermidis in dual species biofilms. J. Food Saf. 30:954-968.

Zhao, T., M. P. Doyle, and P. Zhao. 2004. Control of Listeria monocytogenes in a biofilm by competitive-exclusion microorganisms. Appl. Environ. Microbiol. 70:3996-4003. 